\title{
The Engineering Compliance Program Development Process and its Role in Design"
}

\section{Introduction}

This paper presents an overview of the Engineering Compliance Program (ECP) development process and its role in design. The ECP is a formal program to assess Nuclear Regulatory Commission (NRC) regulatory guidance in terms of precedence, industry experience documents, and codes and standards to determine their applicability to Mined Geologic Disposal System (MGDS) design. These determinations are documented in ECP Guidance Packages for MGDS Structures, Systems and Components (SSCs). This ensures that the license application appropriately reflects the MGDS design and facilitates NRC acceptance and compliance review.

\section{Work Description}

Implementation of the ECP will ensure that the MGDS design is consistent with applicable NRC regulatory precedence, industry experience documents, and codes and standards. The development of the ECP is undertaken in order to facilitate the timely NRC staff acceptance and compliance reviews of the license application to construct a mined geologic repository for the disposal of high-level radioactive waste (HLW). The DOE will, therefore, submit a complete and high-quality license application that is based on the rule of "no surprises" by addressing the design of the MGDS against acceptance criteria in the Technical Guidance Document for Preparation of the License Application (TGD) ${ }^{1}$.

The TGD is structured on the Format and Content for the License Application for the High- 
Level Waste Repository (NRC, 1990) ${ }^{2}$ and the License Application Review Plan for a Geologic Repository for Spent Nuclear Fuel and High-Level Radioactive Waste (LARP)(NRC,1995) ${ }^{3}$. The TGD also follows the format, where applicable, in NRC Standard Review Plans for nuclear power plants (NRC, 1987), low-level radioactive waste disposal facilities (NRC, 1994)', dry cask storage systems (NRC, 1996a) ${ }^{6}$ and spent fuel dry storage facilities (NRC, 1996b) ${ }^{7}$.

The acceptance criteria in the TGD are derived from ECP Guidance Packages that assess methods or solutions found acceptable to NRC staff in NRC regulatory guides, industry codes and standards, Staff Technical Positions, Staff Positions, Standard Review Plans, Safety Evaluation Reports, NRC Case Law, Generic Bulletins, etc. ECP Guidance Packages also provide input to the development of design criteria in the System Description Documents (SDDs) upon which the MGDS design is based by identifying methods or solutions found acceptable to the NRC staff that provide an adequate design and licensing basis for a determination of compliance with NRC licensing requirements. ECP Guidance Packages also support the development of Engineering Design Guides (EDGs) and design analyses related to Design Basis Events (DBEs). The interfaces between the ECP, MGDS design, SDDs, TDG, EDGs and DBEs is provided

\footnotetext{
"This work was supported by the Yucca Mountain Site Characterization Office as part of the Civilian Radioactive Waste Management Program. This project is managed by the U.S. Department of Energy, Yucca Mountain Site Characterization Project.
} 


\section{in Figure 1.}

The ECP, therefore, is at the crossroad of MGDS design, licensing and design criteria development activities and provides a trail of how regulatory and licensing precedents woven into design criteria have been addressed in MGDS design. The ECP also provides for a rigorous process of documenting deviations between the MGDS design and regulatory precedents, including the rationale for such deviations.

ECP Guidance Packages for SSCs are prepared, revised, and maintained pursuant to Nevada Implementing Line Procedure Draft NLP-3-36, Development of Engineering Compliance Program Guidance Packages, and subject to Quality Assurance requirements to ensure that the ECP development process is adequately controlled and the results are reliable. An ECP Guidance Package development flowchart is provided in Figure 2.

As illustrated by Figure 2, the process of developing ECP Guidance Packages essentially requires the following steps:

(a) identifying an SSC or a subordinate SSC for which an ECP Guidance Package needs to be prepared;

(b) preparing and reviewing potentially applicable regulatory guidance documents and codes and standards;

(c) identifying regulatory criteria and performing evaluations to ensure that an appropriate level of detail is captured that will satisfy NRC staff that the commensurate 10 CFR Part 60 regulation has been acceptably implemented; 
(d) identifying licensing precedence that capture NRC staff prior discussions concerning acceptance criteria related to design, functions, procedures, analytical methods, etc. that are acceptable in meeting regulatory requirements;

(e) identifying industry codes and standards and checking them against NRC accepted codes and standards;

(f) specifying bases for assumptions;

(g) identifying rationale for applicability of guidance, both for guidance determined to be applicable and for guidance determined to be not applicable; and

(h) specifying applicable regulatory criteria, licensing precedence and codes and standards on guidance sheets for each of the following eleven criteria fields: (1) site environment and natural systems; (2) physical structures; (3) systems design; (4) operations; (5) surveillance and testing; (6) maintenance; (7) interfacing systems; (8) safety; (9) performance confirmation; (10) performance and safety assessment; and (11) repository programs.

\section{Conclusion}

It is clear that the ECP provides a reasonable, proactive, and rigorous approach to ensuring that the MGDS design meets applicable codes and standards and is consistent with established regulatory precedents. The ECP will support the development of a defensible license application which will facilitate NRC's timely, and successful review. In a time when NRC regulatory environment is focused on ensuring that licensee design and licensing bases are well established and controlled, the ECP process provides that forcing function and controls early in MGDS development to support a well developed, safe, and robust MGDS design. 


\section{References}

1. YMP 1997. Technical Guidance Document for Preparation of the License Application, DOE, YMP/97-03Q. Revision 0, Draft A. Las Vegas, Nevada: Yucca Mountain Site Characterization Project.

2. NRC 1990. Format and Content for the License Application for the High-Level Waste Repository. DG-3003. Washington, D.C.: U.S. Government Printing Office

3. NRC 1995. License Application Review Plan for a Geologic Repository for Spent Nuclear Fuel and High-Level Radioactive Waste. NUREG-1323. Rev. 01. Washington, D.C.: U.S. Government Printing Office.

4. NRC 1987. Standard Review Plan for the Review of Safety Analysis Reports for Nuclear Power Plants, NUREG-0800. Washington, D.C.: U.S. Government Printing Office

5. NRC 1994. Standard Review Plan for the review of a License Application for a Low-Level Radioactive Waste Disposal Facility, NUREG-1200, Rev. 3. Washington, D.C.: U.S. Government Printing Office

6. NRC 1996a. Standard Review Plan for Dry Cask Storage Systems, NUREG-1536.

Washington, D.C.: U.S. Government Printing Office 
7. NRC 1996b. Standard Review Plan for Spent Fuel Dry Storage Facilities, Draft NUREG1567. Washington, D.C.: U.S. Government Printing Office 


\section{ECP Process}

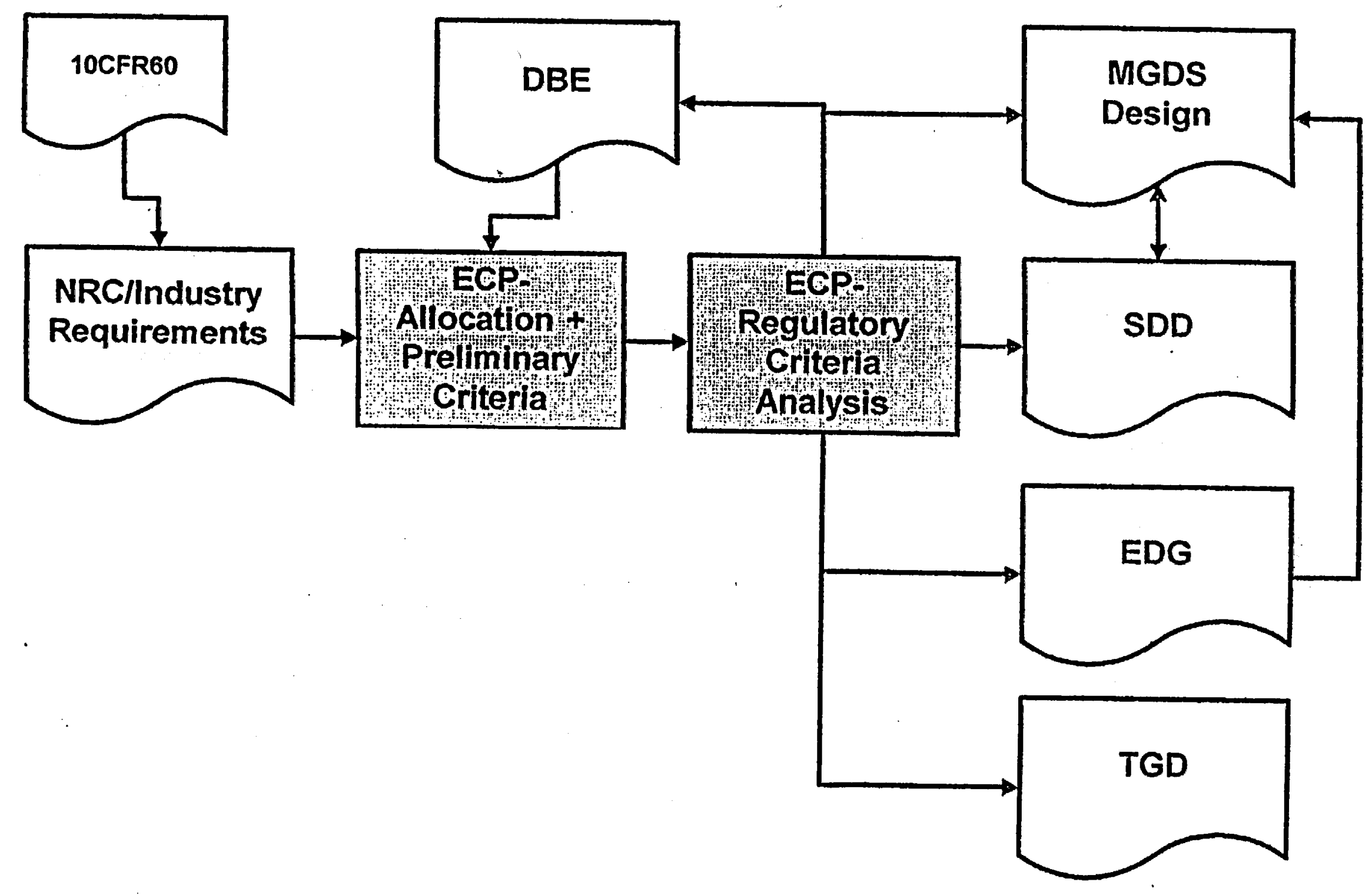




\section{Guidance Package \\ Preparation}
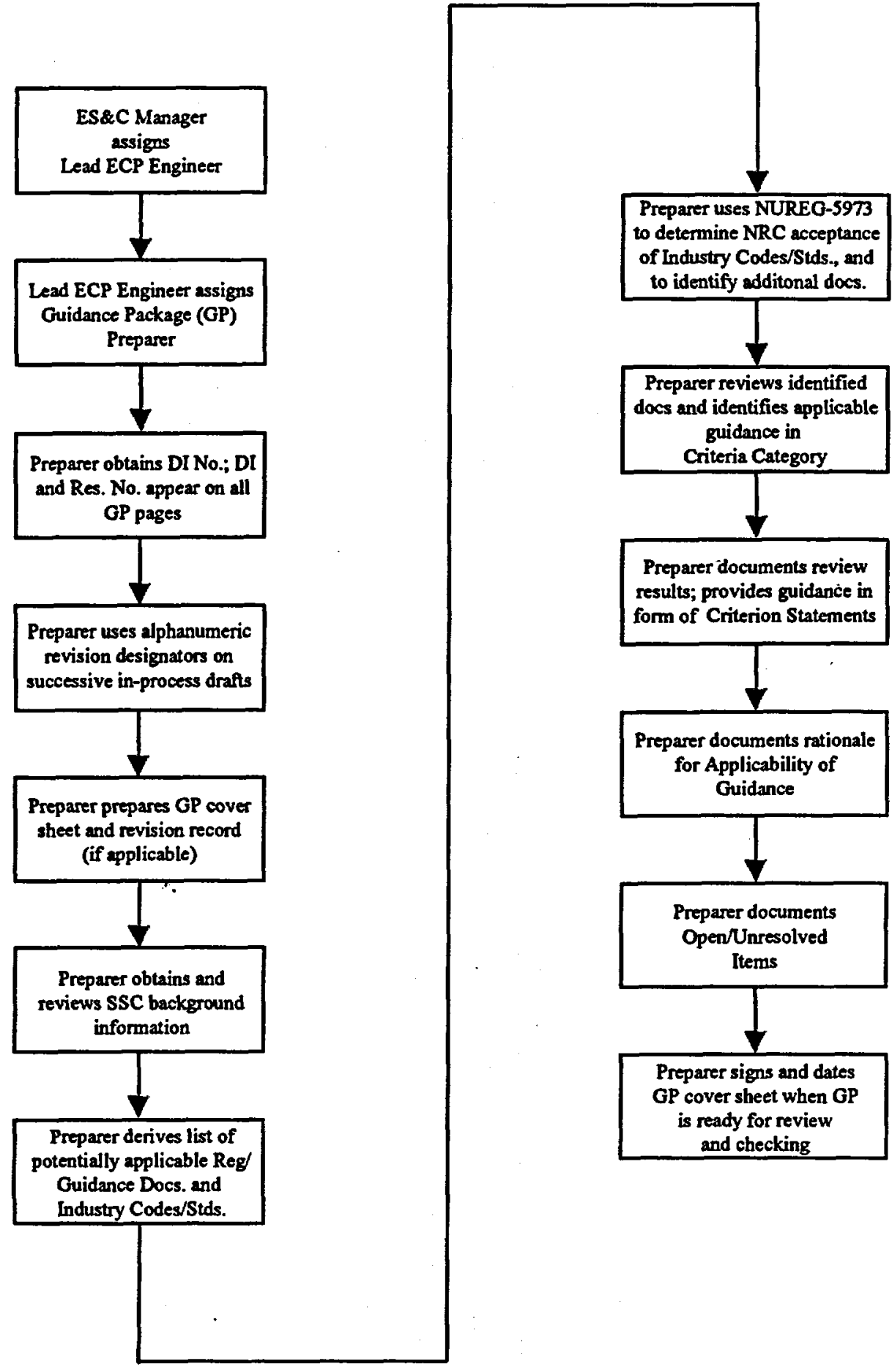

Figure 2 